\title{
Fatal outcome of early postoperative myocardial infarction after implantation of aortic valve bioprosthesis and left internal thoracic artery anastomosis to left anterior descending coronary artery caused by closure of unchanged circumflex coronary artery
}

\author{
Wczesny zawał okołooperacyjny u chorego po implantacji bioprotezy \\ aortalnej i wszczepieniu tętnicy piersiowej wewnętrznej do gałęzi zstępującej \\ przedniej spowodowany zamknięciem niezmienionej tętnicy okalającej, zakończony \\ niepomyślnie
}

Karol Bartczak ${ }^{1}$, Piotr Kula ${ }^{1}$, Radosław Zwoliński ${ }^{1}$, Arkadiusz Ammer ${ }^{1}$, Anna Kośmider ${ }^{1}$, Andrzej Walczak ${ }^{1}$, Andrzej Banyś ${ }^{2}$, Ryszard Jaszewski ${ }^{1}$

${ }^{1}$ Cardiac Surgery Department, Medical University of Łódź

${ }^{2}$ Anesthesiology and Intensive Care Unit, Medical University of Łódź

Kardiochirurgia i Torakochirurgia Polska 2012; 9 (4): 424-427

\begin{abstract}
Acute perioperative myocardial infarction caused by coronary artery embolization after aortic valve implantation is a rare and often fatal postoperative complication. We present a case report of a 67-year-old patient operated on for aortic valve replacement (AVR) and myocardial revascularization (LITA-LAD anastomosis). Myocardial ischemia caused by occlusion of the previously intact circumflex coronary artery occurred in the early postoperative period. Despite a successful balloon angioplasty of the closed artery in the fifth hour after the procedure, the status of the patient did not improve significantly. A decrease in progressive arterial pressure, multiple organ failure, a significant rise of myocardial necrosis markers and the lack of external pacing led to death on the second day after the operation. Acute myocardial infarction after aortic valve replacement caused by occlusion of coronary vessels by calcium debris or thrombosis is a rare postoperative complication, which may be fatal even if the patency of the vessel is promptly restored.

Key words: perioperative myocardial infarction, aortic valve replacement, coronary artery embolism.
\end{abstract}

\section{Streszczenie}

Ostry zawał okołooperacyjny po implantacji zastawki aortalnej spowodowany zatorem do naczyń wieńcowych jest rzadkim powikłaniem, które obarczone jest wysoką śmiertelnością. Przedstawiono przypadek 67-letniego chorego po implantacji bioprotezy aortalnej i rewaskularyzacji serca (LIMA do LAD). We wczesnym okresie pooperacyjnym doszło do ostrego niedokrwienia mięśnia sercowego, które było spowodowane okluzją niezmienionej wcześniej tętnicy okalającej. Pomimo skutecznej plastyki balonowej i udrożnienia zamkniętego naczynia w 5. godzinie po zabiegu stan chorego nie poprawił się istotnie. Postępujący spadek ciśnienia, niewydolność wielonarządowa, bardzo istotne zwiększenie poziomu markerów martwicy mięśnia sercowego oraz brak odpowiedzi na stymulację zewnętrzną doprowadził w 2. dobie po operacji do niepomyślnego zakończenia w opisywanym przypadku. Ostre niedokrwienie w przebiegu po implantacji zastawki aortalnej spowodowane okluzją tętnicy wieńcowej przez masy wapienne bądź skrzeplinę nie jest częstym powikłaniem, ale nawet pomimo szybkiego udrożnienia zamkniętego naczynia w wielu przypadkach nie zawsze kończy się pomyślnie.

Słowa kluczowe: zawał okołooperacyjny, wymiana zastawki aortalnej, zator tętnicy wieńcowej. 


\section{Case report}

The authors present a case of a 67-year-old man operated on for critical aortic stenosis (peak aortic gradient $108 \mathrm{~mm} \mathrm{Hg}$, mean $67 \mathrm{~mm} \mathrm{Hg}$, aortic valve area $0.8 \mathrm{~cm}^{2}$ ), severe calcific degeneration as well as fibrosis of the leaflets and the annulus involving the mitral valve, with ejection fraction of $47 \%$. Coronary angiography revealed an isolated long proximal 95\% narrowing in the left descending artery; all other coronary arteries were without any lesions (Fig. 1). ECG showed a $1^{\text {st }}$ degree AV block (PR 230-250 ms). The fibrinogen level was $7.5 \mathrm{~g} / \mathrm{l}$ and the thrombin time was $24 \mathrm{~s}$. An Aortic Medtronic Hancock 23 A supra annular bioprosthesis had been implanted with concomitant cardiac artery bypass of the left internal thoracic artery to the left descending artery in extracorporeal circulation. Intraoperative examination revealed massive calcific degeneration within the three leaf-

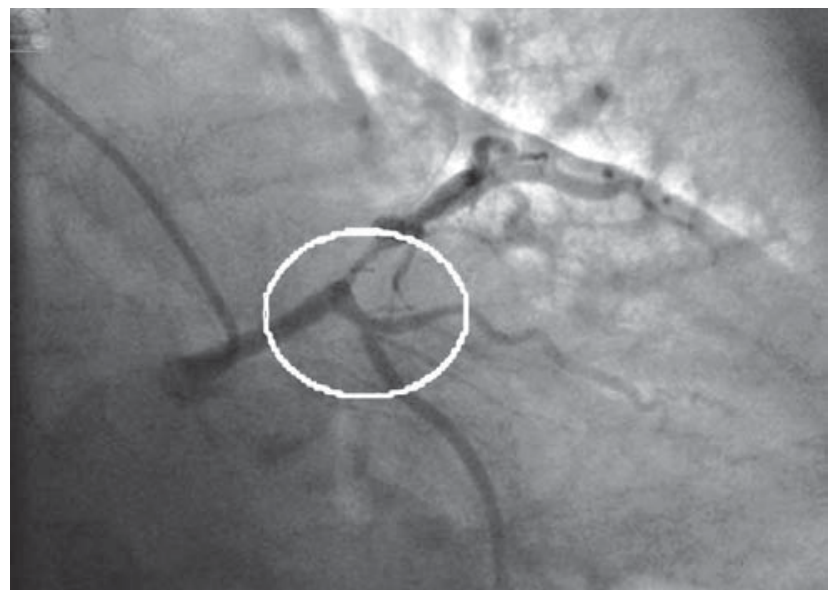

Fig. 1. Coronary angiogram of the left coronary artery before the operation (the circle indicates the unchanged circumflex coronary artery)

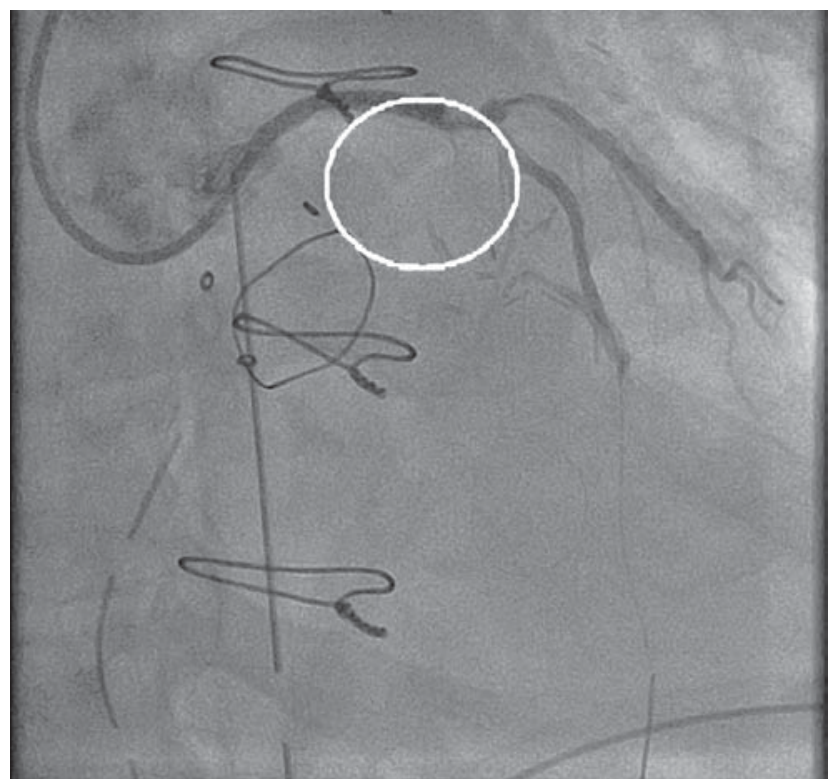

Fig. 2. Coronary angiogram of the left coronary artery after the operation (the circle indicates the closed circumflex coronary artery) lets of the functionally bileaflet aortic valve and the annulus, reaching the intraventricular septum and the anterior leaflet of the mitral valve. The aortic cross-clamping time was 101 minutes and the extracorporeal circulation time was 130 minutes. Cold crystalloid antegrade cardioplegic solution was used for cardiac protection, administered directly to the ostia of the left and right coronary arteries (dosage: $20 \mathrm{ml} / \mathrm{kg}$ of body weight every 20 minutes). After declamping the aorta and restarting the heart, we observed a $3^{\text {rd }}$ degree AV block. An epicardial cardiostimulator was introduced. After 23 minutes of reperfusion with effective heart stimulation, the extracorporeal circulation was stopped. There was no need for the use of catecholamines. The patient was then transferred to a postoperative room in stable condition. After 3 hours, the patient's condition destabilized. We noted a progressive decrease in arterial blood pressure, at which point we introduced an infusion of catecholamines in increasing doses and used an intra-aortic balloon pump (IABP) - with little response. ECG reveled ischemia of the lateral and posterior walls of the heart. Transesophageal echocardiography showed hypo/akinesia of the lateral and posterior walls of the heart, weakening of the global contraction function with ejection fraction of $36 \%$ and proper functioning of the prosthesis with no signs of perivalvular leak. Due to the lack of a positive response to the provided treatment, in the $5^{\text {th }}$ postoperative hour, the patient was referred for immediate coronary angiography, which revealed the amputation of the initially unchanged circumflex artery and an additional $90 \%$ narrowing of the medial segment of the left descending artery. The left thoracic artery was narrowed, but flow was preserved (Fig. 2). Percutaneous cardiac intervention was performed with the implantation of 2 bare-metal stents in the proximal and medial segments of the left descending artery with TIMI 3 grade flow and balloon angioplasty of the circumflex artery with TIMI 3 grade flow (Fig. 3). Despite

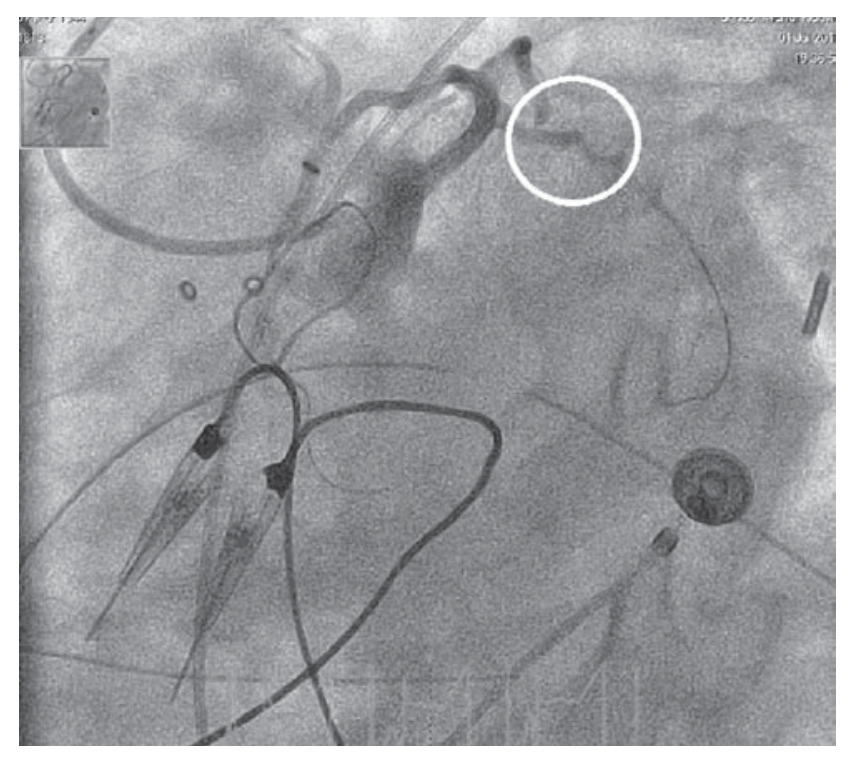

Fig. 3. Coronary angiogram of the left coronary artery after the successful opening of the circumflex artery (the circle indicates the opened circumflex coronary artery) 
the successful percutaneous cardiac intervention on the amputated and narrowed coronary arteries and the initial improvement, the patient's condition declined during the first postoperative day. The patient exhibited a gradual decrease in artery blood pressure, anuria (continuous veno-venous hemodiafiltration was performed), elevation of myocardial infarction markers (elevation of high-sensitivity troponin $\mathrm{T}$ from 2840 to $10000 \mathrm{ng} / \mathrm{ml}$ ) and multi-organ failure. On the second postoperative day, death was pronounced due to the lack of response of the heart to cardiostimulation and the continuous decrease of artery blood pressure (to an indeterminable level) despite resuscitation.

\section{Discussion}

Perioperative myocardial infarction after aortic valve replacement caused by embolus is a very rare, but serious and potentially lethal complication. Symptoms of myocardial ischemia, such as low cardiac output syndrome, depend on which cardiac vessel is obstructed. According to the literature, occlusion of the left main trunk is one of the most serious and dangerous complications after aortic or mitral valve replacement [1, 2] and it occurs in 1 to $5 \%$ of patients without any changes in the coronary arteries prior to surgery [1].

In many cases, early acute myocardial ischemia may be caused by technical mistakes during the implantation of artificial valves. Implanting an oversized artificial valve whose edges could occlude the coronary ostia and disable proper coronary artery perfusion may serve as an example [3]. Microinjuries, local immunological and hyperplastic reactions related to the infusion pressure of cardioplegia, and the low temperature of the cardioplegic solution administered directly to the ostia of the coronary arteries constitute other possible explanations for myocardial ischemia after AVR. However, myocardial ischemia in such cases occurs later in the postoperative period [4, 5].

In patients with acute myocardial ischemia after AVR, it is important to take into consideration the ostial or proximal narrowing or occlusion of the coronary artery due to coronary artery spasm or calcium embolism related to aortic valve decalcification, thrombus, bacterial embolism or air $[6,7]$. In these cases, coronary artery occlusion may cause difficulties in restoring circulation after extracorporeal circulation or recurrent ventricular fibrillation.

We described a case of a patient who, in the $3^{\text {rd }}$ postoperative hour, developed myocardial ischemia which then continued to progress. Analyzing the possible causes, we have to take into consideration the calcific embolism released during normal heart activity or thrombus. Preoperative coronary angiography revealed a proximal narrowing in the left descending artery just before the orifice of the circumflex artery (Fig. 2), which may explain the circumflex artery occlusion.

In the majority of publications, the authors indicate the necessity of immediate coronary angiography in cases of decreased artery blood pressure, ventricular arrhythmias, and progressing acute heart insufficiency during the early postoperative period after aortic valve replacement [6-8].
It is not advisable to wait for the elevation of cardiac ischemia markers.

The control coronary angiography performed in the $5^{\text {th }}$ postoperative hour enabled us to confirm our previous presumptions concerning the circumflex coronary artery occlusion, successfully restore the flow in this vessel, and perform a percutaneous intervention in the primary narrowed left descending artery. It seems that our reaction was correct and the achieved TIMI 3 grade flow in the occluded artery significantly improved our prognosis. Unfortunately, it did not save the patient. Presumably, irreversible lesions in the microcirculation had already developed.

Balloon coronary angioplasty and stent implantation are the quickest methods of restoring the flow in the occluded coronary artery either in the left main or proximal segment $[9,10]$. However, it should be emphasized that this method is not successful in every case. Sometimes surgical revascularization of the heart is the only option, despite the much higher risk. Leontiew et al. presented a case of postoperative myocardial infarction caused by closure of the left main coronary artery in a 62-year-old patient after aortic bioprosthesis implantation. The patient underwent off-pump coronary artery bypass grafting with the implantation of two saphenous grafts to the left descending artery and the circumflex artery. Postoperatively, extracorporeal membrane oxygenation support had to be employed for 10 days and was extremely complicated. Despite that, the patient was discharged from the hospital after three months [8].

\section{Conclusions}

Acute myocardial ischemia caused by coronary occlusion resulting from calcium debris or thrombus, taking place early after aortic valve replacement, is not a common complication. Despite prompt intervention, it may be fatal in many cases.

This paper was presented at the Torakoneptunalia 2011 Conference, Jurata 23-24 of September 2011.

\section{Literature}

1. Funada A, Mizuno S, Ohsato K, Murakami T, Moriuchi I, Misawa K, Kokado H, Shimada Y, Ishida K, Ohashi H. Three cases of iatrogenic coronary ostial stenosis after aortic valve replacement. Circ J 2006; 70: 1312-1317.

2. Calafiore AM, lacò AL, Varone E, Bosco P, Di Mauro M. Distortion of the proximal circumflex artery during mitral valve repair. J Card Surg 2010; 25: 163-165.

3. Turillazzi E, Di Giammarco G, Neri M, Bello S, Riezzo I, Fineschi V. Coronary ostia obstruction after replacement of aortic valve prosthesis. Diagn Pathol 2011; 6: 72.

4. Gruber S, Ng CK, Schwarz C, Auer J. Unstable angina early after aortic valve replacement surgery in a female patient with normal coronary arteries preoperatively - a case report. J Cardiothorac Surg 2009; 4: 29.

5. Goździk A, Pelczar M, Skalik R, Obremska M, Goździk W, Kustrzycki W. Zawał okołooperacyjny u pacjentki bez zmian w naczyniach wieńcowych poddanej planowej operacji wymiany zastawki aortalnej. Kardiochirur Torakochirur Pol 2007; 4: 199-203.

6. Umran S, Chetty G, Sarkar PK. Acute right coronary ostial stenosis during aortic valve replacement. Int J Prev Med 2012; 3: 295-297.

7. Levis JT, Schultz G, Lee PC. Acute myocardial infarction due to coronary artery embolism in a patient with a tissue aortic valve replacement. Perm J 2011; 15: 82-86. 
8. Leontyev S, Borger MA, Battellini R, Seeburger J, Lehmann S, Légaré JF, Mohr FW. Embolic occlusion of the left main coronary artery following an isolated aortic valve replacement. J Card Surg 2011; 26: 168-170.

9. Ziakas AG, Economou FI, Charokopos NA, Pitsis AA, Parharidou DG, Papadopoulos TI, Parharidis GE. Coronary ostial stenosis after aortic valve replacement: successful treatment of 2 patients with drug-eluting stents. Tex Heart Inst J 2010; 37: 465-468.

10. Raja Y, Routledge HC, Doshi SN. Coronary stenting for iatrogenic stenosis of the left main coronary artery post-aortic valve replacement: an alternative treatment? Eur J Cardiothorac Surg 2011; 39: 398-400. 